\title{
DETERMINATION OF CHANGES IN VOLUME AND ELEVATION OF GLACIERS USING DIGITAL ELEVATION MODELS FOR THE VERNAGTFERNER, ÔTZTAL ALPS, AUSTRIA
}

by

\author{
W. Reinhardt and H. Rentsch
}

(Technical University and Bavarian Academy of Science, Münich, West Germany)

\begin{abstract}
The paper deals with the determination of changes in volume and elevation of glaciers, using Digital Elevation Models (DEM). First, the generation of a DEM is briefly described and the method of determining changes in volume and elevation by using DEMs is introduced. A brief description of the determination of these changes by means of contour plots follows. A comparison of both methods with respect to accuracy and economy is carried out on part of the Vernagtferner. The results from these investigations show that a required accuracy level can be obtained more economically by using DEMs. The changes in volume and elevation for the whole glacier area are determined by means of DEMs, for 1979 and 1982. The paper concludes with comments on the results and a review of other applications of DEMs.
\end{abstract}

\section{INTRODUCTION AND SURVEY}

For about one hundred years, scientists have been engaged in determining the changes of the surface of glaciers. In the special case of the Vernagtferner, accurate topographic maps have been available since 1889 and were used for the calculation of changes in volume and elevation of the glacier (Brunner and Rentsch 1972). These changes of the surface of glaciers were deduced from contour plots of different years. The contours had to be digitized, using planimeters in most cases. As already mentioned in Peipe and others (1978), the data processing for this method is rather complicated and inconvenient. In this paper, the use of Digital Elevation Models (DEM), or equivalent Digital Terrain Models (DTM), for the determination of changes in volume and elevation of the glacier, will be introduced. First, the generation of a DEM and the determination of changes in volume and elevation from the DEM are described. Next, the contour method is briefly described and a comparison between both methods is carried out on part of the Vernagtferner, for the years 1979 and 1982. The changes in volume and elevation for the whole glacier area, deduced from the DEMs, are presented and the paper concludes with comments on the results.

\section{GENERATION OF DIGITAL ELEVATION MODELS}

The Digital Elevation Model is a description of a surface (especially the terrain surface), by digital means. So-called regular DEMs have some advantages concerning data processing and storage and were used here, too. The meshes of a regular DEM form a square grid in plane. The elevations of the grid points can be measured directly in the stereo mode, or interpolated from arbitrarily-distributed reference points.

Data acquisition

Density and distribution of the measured reference points determine the quality of the final DEM substantial. A survey of techniques of photogrammetric data acquisition is given in Ebner and Eder (1984). For the data acquisition of the DEMs, we used Vernagtferner registrated contour lines in 1979 and the method of Progressive Sampling in 1982.

For the year 1979, the task consisted of direct contour plotting, on the one hand, and the determination of the controlling profiles for an analytical orthoprojector, on the other (Rentsch 1982). For this reason, contour plotting was done with the analytical plotter, Zeiss Planicomp C 100. Simultaneously, the intersections of the contour lines with a regular grid were recorded. Additionally, break lines were measured.

For the year 1982, the program PROSA (Reinhard 1984) was used for data acquisition. This program runs in conjunction with the analytical plotters, Zeiss Planicomp, and is based on the method of Progressive Sampling. Data acquisition starts with the measurement of break lines and a sparse grid, which subsequently is densified, according to the local shape of the terrain and the accuracy requirement. DEM Interpolation

For DEM Interpolation, various algorithms and computer programs are available (e.g. Kraus 1984). The DEMs of the Vernagtferner were interpolated with the mini-computer program, HIFI (Height Interpolation by Finite Elements) (Ebner and others 1980), of the Chair of Photogrammetry TU Munich. HIFI interpolates the elevations of grid points from the elevations of arbitrarily-distributed reference points and points along break lines. More details concerning DEM data acquisition and interpolation using PROSA and HIFI are given in Ebner and Reinhardt (1984).

All computational work concerning DEMs in this paper, such as interpolation of DEMs, derivation of contours and volumes was done with the HIFI program system mentioned above.

\section{DETERMINATION OF CHANGES IN VOLUME AND ELEVATION FROM DIGITAL ELEVATION MODELS \\ Calculation of volume}

For the calculation of volume, using a regular DEM, the volumes of quadratic pillars have to be summed up. The quadratic pillars are limited by a horizontal square on

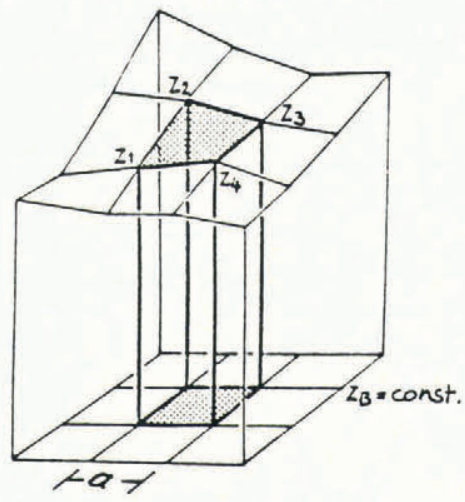

Fig.1. 
the bottom and a hyperbolic paraboloid on the top (see Fig.1).

The volume of one of these quadratic pillars can be calculated from equation (1) (Kraus 1984).

$$
V_{a}=K\left(Z_{1}-Z_{B}+Z_{2}-Z_{B}+Z_{3}-Z_{B}+Z_{4}-Z_{B}\right) f q
$$

with $\mathrm{fq}=\mathrm{a}^{2}, \quad \mathrm{a}=$ grid width

The whole volume within the rectangular DEM area can then be caluclated from:

$v_{Z_{B}}=\left(\sum_{i=1}^{4} 1 / 4\left(Z_{C_{i}}-Z_{B}\right)+\sum_{i=1}^{n_{1}} 1 / 2\left(Z_{M_{i}}-Z_{B}\right)+\sum_{i=1}^{n_{2}}\left(Z_{I_{i}}-Z_{B}\right)\right) f q$

with:

$Z_{B}$ - the elevation of the horizontal plane $Z_{B}=$ const $\mathrm{Z}_{\mathrm{C}}$ - the elevations of the four corner points of the

$Z_{M_{i}}-\quad$ the elevations of the $n_{1}=2 n_{x}+2 n_{y}-8$ other margin
point of the DEM

$\mathrm{Z}_{I_{1}}-\quad$ the elevations of the $\mathrm{n}_{2}=\left(\mathrm{n}_{\mathrm{x}}-2\right)\left(\mathrm{n}_{\mathrm{y}}-2\right)$ other
points of the DEM

$\mathrm{n}_{\mathrm{x}}$ - the number of points in $\mathrm{x}$-direction of the DEM

$\mathrm{n}_{\mathrm{y}}$ - the number of points in $\mathrm{y}$-direction of the DEM

\section{Changes in volume}

To determine changes in volume, two DEMs, from two different epochs, have to be available. These DEMs have to cover the same area and must have identical grids in plane. In glacier research, it is usual to specify changes in volume for $100 \mathrm{~m}$ intervals. Therefore, the volume of each DEM, defined by two horizontal planes with a difference in elevation of $100 \mathrm{~m}$, has to be computed. These volumes are ontained from equation (2) by setting $Z_{B}$ on a level with these horizontal planes subsequently for both years. The

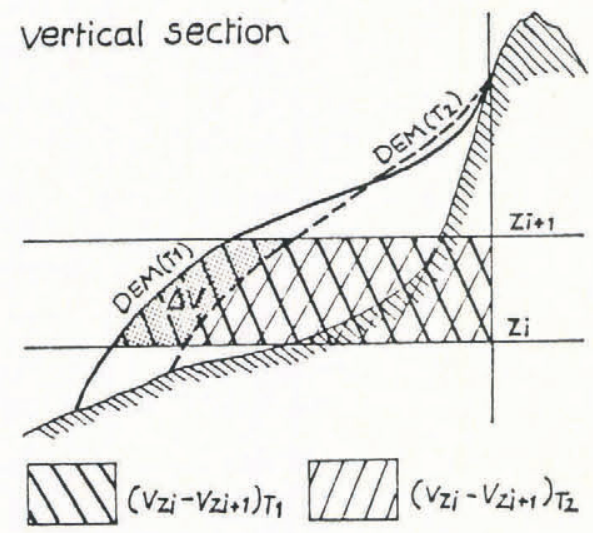

Fig.2.

difference in volume corresponding to the epochs $\mathrm{T} 1$ and $\mathrm{T} 2$ and the horizontal planes $\mathrm{Z}_{\mathrm{i}}$ and $\mathrm{Z}_{\mathrm{i}+1}$ (see Fig.2) is then given by:

$\Delta \mathrm{V}_{\mathrm{Z}_{\mathrm{i}}, \mathrm{Z}_{\mathrm{i}+1}}=\left(\mathrm{V}_{\mathrm{Z}_{\mathrm{i}}}-\mathrm{V}_{\mathrm{Z}_{\mathrm{i}+1}}\right) \mathrm{T}_{2}-\left(\mathrm{V}_{\mathrm{Z}_{\mathrm{i}}}-\mathrm{V}_{\mathrm{Z}_{\mathrm{i}+1}}\right) \mathrm{T}_{1}(3)$

\section{Changes in elevation}

The change in elevation of different epochs will be defined as the mean value of the differences in elevation, $\Delta \mathrm{h}_{\mathrm{i}}$, of the $\mathrm{n}$ DEM points:

$$
\Delta \mathrm{h}_{\mathrm{m}}=\frac{\sum_{\mathrm{i}=1}^{\mathrm{n}} \Delta \mathrm{h}_{\mathrm{i}}}{\mathrm{n}}
$$

To calculate this mean value with respect to the $100 \mathrm{~m}$ intervals, the differences, $\Delta \mathrm{h}_{\mathrm{i}}$, for each $100 \mathrm{~m}$ interval have to be summed up and their number has to be counted. With these specific values, the mean value of a $100 \mathrm{~m}$ interval can be calculated from equation (4).

Practical aspects

From a theoretical point of view, it is sufficient to establish two DEMs of different epochs, which are covering the same area and have grid points with identical coordinates in plane, and use them for the calculation of changes in volume and elevation. But, in practice, the data acquisition of the different DEMs can be systematically affected by different orientations and/or operators. To make sure that uncontrolled systematic errors are avoided, in practice, it is useful to transform the measured terrain coordinates of one epoch on to the terrain coordinates of the other epoch. For this purpose, in both cases, identical points have to be measured. This kind of point can be found at the surrounding rock areas of the glacier. For a final test, it is recommendable to derive contours from the DEMs after this transformation and to compare these contours in the surrounding areas.

In general, the regular grid DEM of the glacier also covers areas where no change in elevation should occur. To ensure that effects from random errors of the measurement in these areas do not interfere with the calculation of the changes in volume and elevation within the surface of the glacier, it is best to avoid calculations in there. For this reason, the outlines of the glacier surface have to be recorded in the stereo model.

DETERMINATION OF CHANGES IN VOLUME AND ELEVATION, USING THE CONTOUR METHOD

This method should be briefly introduced here, because it is compared later with the method introduced above. For the determination of changes in volume and elevation, contour plots of two different epochs are required. The contour plots have to coincide in areas beyond the glacier surface

Figure 3 shows contours from two different epochs, T1 and $\mathrm{T} 2$. The areas $\mathrm{F} 1, \mathrm{~F} 2, \Delta \mathrm{F} 1, \Delta \mathrm{F} 2$ have to be determined

horizontal projection
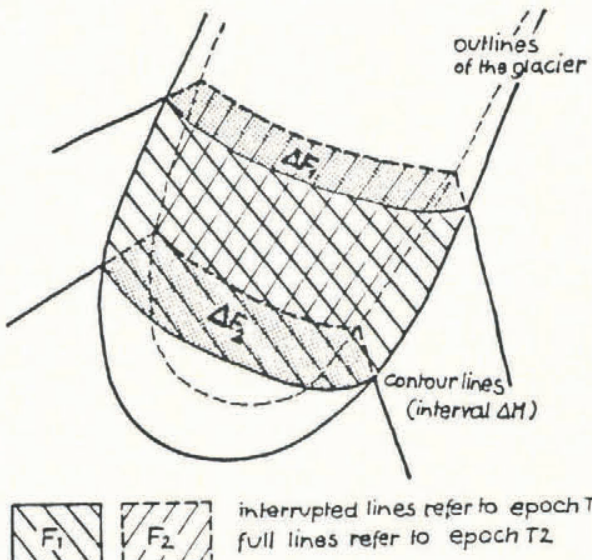

Fig.3.

planimetrically. From these values and the contour interval, $\Delta \mathrm{H}$, the desired changes of the glacier can be calculated from equations ( 5 and 6 ) (for details see R. Finsterwalder 1953).

$\Delta \mathrm{h}=\frac{\Delta \mathrm{F}_{1}+\Delta \mathrm{F}_{2}}{\mathrm{~F}_{1}+\mathrm{F}_{2}} \cdot \Delta \mathrm{H} \quad$ (5) $\quad \Delta \mathrm{V}=\frac{\Delta \mathrm{F}_{1}+\mathrm{F}_{2}}{2} \cdot \Delta \mathrm{H}$

COMPARISON OF THE TWO METHODS ON PART OF THE VERNAGTFERNER

To compare the different methods introduced in sections 3 and 4 , with respect to economy and accuracy, both methods were applied to determine changes in volume 


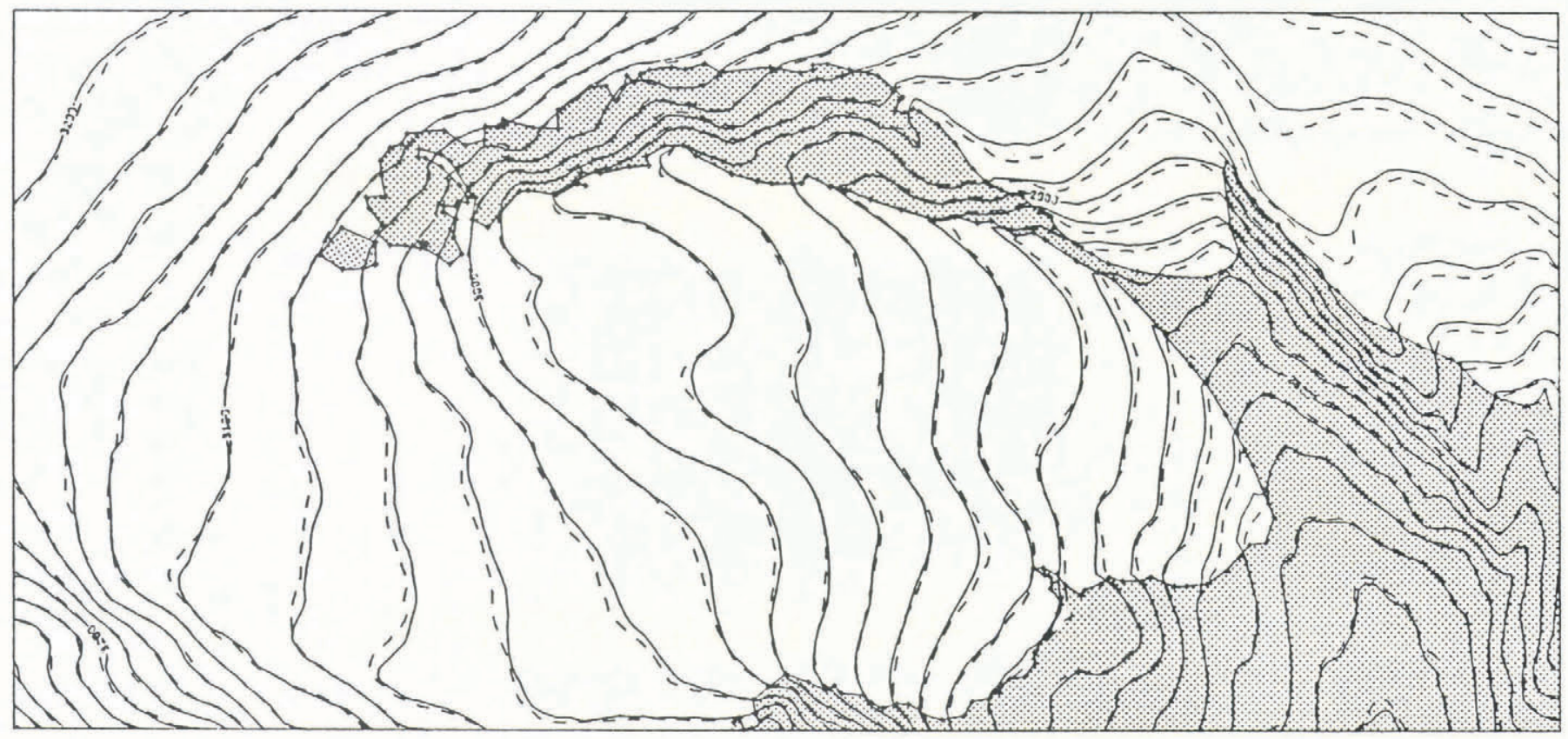

Fig.4. $20 \mathrm{~m}$ contours derived from the $20 \mathrm{~m}$ DEMs 1979 (continuous line) and 1982 (interrupted line) and outlines of the glacier for a sub-area of the Vernagtferner.

and elevation on part of the Vernagtferner. Because planimetric work requires a lot of time, the area was limited to $2500 \times 1140 \mathrm{~m}^{2}$

All the measurements necessary for this paper were obtained from the following material:

- seven stereo models covering the Vernagtferner area; images taken on 14. 08. 1979, focal length $153 \mathrm{~mm}$, image scale 1:20000

- two stereo models covering the Vernagtferner area; images taken on 14.09. 1982, focal length $153 \mathrm{~mm}$, image scale 1:33000

For these investigations, first, a dense $20 \mathrm{~m}$ square DEM (7308 points) was measured directly for both epochs, using an Analytical Plotter, Zeiss Planicomp. Next, for 1979, a direct contour plot was drawn and digital contours were derived from the $20 \mathrm{~m}$ DEM. As also shown in Rentsch (1982), the direct contour plot and the digital contours were identical on the glacier surface. For that reason, digital contours derived from both $20 \mathrm{~m}$ DEMs were used for the determination of changes of the glacier by the contour method. Thus, the comparison now is performed with the same data sets, in order to avoid an influence of different measurements with different random errors. Additionally, the outlines of the glacier surface were recorded.

Figure 4 shows the digital contours derived from $20 \mathrm{~m}$ DEMs of 1979 and 1982. The measured data of 1982 were transformed by identical points on to the system of 1979, as described above.

Now the changes in volume and elevation on this part of the glacier were derived from:

a $20 \mathrm{~m}$ and a $40 \mathrm{~m}$ DEM, where the $40 \mathrm{~m}$ DEM was obtained from the $20 \mathrm{~m}$ DEM

contours with $10 \mathrm{~m}, 20 \mathrm{~m}$ and $50 \mathrm{~m}$ contour interval

For the comparison of the different methods, the results obtained from the dense $20 \mathrm{~m}$ DEM were used as reference. Then the discrepancies between the results from the $20 \mathrm{~m} \mathrm{DEM}$ and the other sets were used for a check of the results from these data sets.

Table I includes the changes in elevation derived from the $20 \mathrm{~m} \mathrm{DEM}$ and the discrepancies between these results and the changes in elevation obtained by using the other sets for the $100 \mathrm{~m}$ intervals and, in the lowest row, for the total area. These latter discrepancies are also given in percentage change in elevation, derived from the $20 \mathrm{~m}$ DEM.

From Table I, we notice that the discrepancies between the results from the $20 \mathrm{~m}$ DEM and $10 \mathrm{~m}$
TABLE.I. CHANGES IN ELEVATION DERIVED FROM 20M DEMS AND DISCREPANCIES BETWEEN THIS AND THE CHANGES IN ELEVATION OBTAINED BY USING CONTOURS AND A 40M DEM.

\begin{tabular}{|c|c|c|c|c|c|}
\hline \multirow[b]{2}{*}{$\begin{array}{c}\text { intervals } \\
{[\mathrm{m}]}\end{array}$} & \multirow{2}{*}{$\begin{array}{l}\text { cranges in } \\
\text { elevation im: } \\
20 m \\
\text { DEM }\end{array}$} & \multicolumn{4}{|c|}{$\begin{array}{l}\text { discrepancies } \mathrm{m}^{3} \text { ? } \\
\text { between } 20 \mathrm{~m} \text { OEM and }\end{array}$} \\
\hline & & $\begin{array}{l}10 \mathrm{~m} \\
\text { contours }\end{array}$ & $\begin{array}{l}20 \mathrm{~m} \\
\text { contours }\end{array}$ & $\begin{array}{l}50 \mathrm{~m} \\
\text { contours }\end{array}$ & $\begin{array}{l}40 \mathrm{~m} \\
\text { OEM }\end{array}$ \\
\hline 3200 & & & & & \\
\hline 3100 & 0.5 & -0.1 & -0.3 & 0.0 & 0.2 \\
\hline & -0.8 & 0.0 & -0.2 & -0.4 & 0.0 \\
\hline 0000 & 1.5 & 0.0 & 0.1 & -0.1 & 0.3 \\
\hline & 1.9 & -0.3 & -0.2 & -0.4 & 0.1 \\
\hline 2700 & 4.3 & -0.8 & -1.0 & 0.4 & 0.1 \\
\hline total & 0.74 & $\begin{array}{r}-0.06 \\
(8 \%)\end{array}$ & $\begin{array}{l}-0.12 \\
(16 \%)\end{array}$ & $\begin{array}{l}-0.17 \\
(22.9 \%)\end{array}$ & $\begin{array}{c}0.16 \\
\left(21.6^{\%}\right)\end{array}$ \\
\hline
\end{tabular}

contours are small in general and the discrepancies for the other data sets are, as we might expect, somewhat bigger. In Table II, the changes in volume derived from the $20 \mathrm{~m}$ DEM and the discrepancies between these results and the changes in volume from the other data sets are given, for the $100 \mathrm{~m}$ intervals and for the total area, in a similar way as in Table $\mathrm{I}$.

We notice that the discrepancy between the results from the $20 \mathrm{~m}$ DEM and the $10 \mathrm{~m}$ contours for the total area is very small. For the single intervals, the discrepancies are somwhat bigget, especially for the interval $3100-3200 \mathrm{~m}$, for which the change in elevation is relatively small. That means that the relative error of the difference volume is bigg $2 r$ in this case compared with that of the other intervals. In addition, the changes in volume derived from contours are not only influenced by the original measurements, but also by the random error of the planimetry, which is also relatively great when the changes in elevation are small.

In Table III, the times required for the generation of the different data sets and the determination of the changes in volume and elevation are given. The latter task includes 
TABLE II. CHANGES IN VOLUME DERIVED FROM 20M DEMS AND DISCREPANCIES BETWEEN THIS AND THE CHANGES IN VOLUME OBTAINED BY USING CONTOURS AND A 40M DEM.

\begin{tabular}{|c|c|c|c|c|c|}
\hline & $\begin{array}{l}\text { changes in } \\
\text { volume }\left[\mathrm{m}^{3}\right]\end{array}$ & & $\begin{array}{l}\text { iscrepanc } \\
\text { etween } 20\end{array}$ & SEM $\left[\mathrm{m}^{3}\right.$ ) & \\
\hline $\begin{array}{c}\text { intervals } \\
{[\mathrm{m}]}\end{array}$ & $\begin{array}{l}20 \mathrm{~m} \\
\text { OEM }\end{array}$ & $\begin{array}{l}10 \mathrm{~m} \\
\text { contours }\end{array}$ & $\begin{array}{l}20 \mathrm{~m} \\
\text { contours }\end{array}$ & $\begin{array}{l}5 \mathrm{Cm} \\
\text { contours }\end{array}$ & $\begin{array}{l}40 m \\
\text { DEM }\end{array}$ \\
\hline $\begin{array}{l}3200 \\
3100 \\
3000 \\
2900 \\
2800 \\
2700\end{array}$ & $\begin{array}{rr}245 & 140 \\
-444 & 090 \\
1237 & 920 \\
583 & 232 \\
122 & 304\end{array}$ & $\begin{array}{r}-39360 \\
24910 \\
47920 \\
-40768 \\
-\quad 196\end{array}$ & 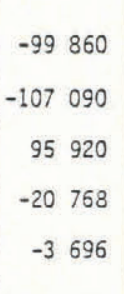 & $\begin{array}{r}27640 \\
-199090 \\
-37080 \\
-71708 \\
29804\end{array}$ & $\begin{array}{rr}91 & 840 \\
-8 & 010 \\
216 & 210 \\
24 & 900 \\
3 & 840\end{array}$ \\
\hline total & 1744506 & $\begin{array}{r}-7494 \\
(0.4 \%)\end{array}$ & $\begin{array}{c}-135494 \\
(7.8 \%)\end{array}$ & $\begin{array}{r}-250494 \\
(14.4 \%)\end{array}$ & $\begin{array}{l}328780 \\
(18.8 \%)\end{array}$ \\
\hline
\end{tabular}

TABLE III. TIME REQUIREMENT OF THE DIFFERENT METHODS.

\begin{tabular}{|l|c|c|c|}
\hline & $\begin{array}{l}\text { time for } \\
\text { data acquisition [h] }\end{array}$ & $\begin{array}{l}\text { time for } \\
\text { determination } \\
\text { of changes }[\mathrm{k}]\end{array}$ & $\begin{array}{c}\text { total time } \\
{[\mathrm{h}]}\end{array}$ \\
\hline $20 \mathrm{~m}$ OEM & 21.1 & 0.5 & 21.6 \\
$10 \mathrm{~m}$ contours & 31.9 & 40.0 & 71.9 \\
$20 \mathrm{~m}$ contours & 20.5 & 20.0 & 40.5 \\
$50 \mathrm{~m}$ contours & 13.7 & 8.0 & 21.7 \\
$40 \mathrm{~m}$ DEM & 12.1 & 0.4 & 12.5 \\
\hline
\end{tabular}

planimetric work and calculations for the contour method and program control and computational time for the DEM method. The times given for the $20 \mathrm{~m}$ and $50 \mathrm{~m}$ contours and for the $40 \mathrm{~m} \mathrm{DEM}$ are estimated from the required times of the $10 \mathrm{~m}$ contours and the $20 \mathrm{~m}$ DEM, respectively. Considering both accuracy and economy, we notice that the results from $10 \mathrm{~m}$ contours and the $20 \mathrm{~m}$ DEM differ little, but using the $20 \mathrm{~m}$ DEM leads to much better economy.

From Table III, we also notice that the time required for the $20 \mathrm{~m} \mathrm{DEM}$ is the same as for $50 \mathrm{~m}$ contours, but the results from the $50 \mathrm{~m}$ contours (see Table I and II) differ a lot from the more dense data sets such as the $20 \mathrm{~m} \mathrm{DEM}$ and the $10 \mathrm{~m}$ contours. Finally, the accuracy of the results obtained fromt the $50 \mathrm{~m}$ contours and the $40 \mathrm{~m}$ DEM is about the same, but with better economy in the case of the $40 \mathrm{~m}$ DEM. Consequently, the determination of changes in volume and elevation, using DEMs, leads to much better economy than using contour plots.

DETERMINATION OF CHANGES IN VOLUME AND ELEVATION FOR THE WHOLE VERNAGTFERNER AREA USING DIGITAL ELEVATION MODELS

For the whole Vernagtferner area of $4960 \times 3680 \mathrm{~m}^{2}$, the following data were measured, as described in chapter 2:

1979: 27655 intersection points of $20 \mathrm{~m}$ contours with a $40 \mathrm{~m}$ grid; 1236 points along the borders of the glacier area.

1982: 15336 reference points, measured using the method of Progressive Sampling; 2043 points along the borders of the glacier area.

With these input data, in both cases, a $20 \mathrm{~m}$ DEM was interpolated (46 065 points). From these DEMs, the changes in volume and elevation were derived for the glacier area, limited by the outer edges of the glacier in both years. Table IV includes these changes in volume and elevation, derived from the $20 \mathrm{~m}$ DEMs for 1979 and 1982, for all $100 \mathrm{~m}$ intervals and for the whole area.
TABLE IV, CHANGES IN VOLUME AND ELEVATION FOR THE WHOLE VERNAGTFERNER AREA BETWEEN 1979 AND 1982 DERIVED FROM 20M DEMs.

\begin{tabular}{|c|c|c|c|}
\hline $\begin{array}{c}\text { intervals } \\
\text { [m] }\end{array}$ & $\begin{array}{c}\text { number } \\
\text { of points }\end{array}$ & $\begin{array}{c}\text { changes in } \\
\text { eievation } \\
{[\mathrm{m}]}\end{array}$ & $\begin{array}{c}\text { changes in } \\
\text { voiume } \\
{\left[\mathrm{m}^{3}\right]}\end{array}$ \\
\hline 3700 & 11 & -1.5 & -6600 \\
3600 & 114 & -1.5 & -67330 \\
3500 & 1280 & -0.6 & -280460 \\
3400 & 2175 & -1.8 & -1514720 \\
3300 & 5484 & -2.0 & -4368020 \\
3200 & 6707 & -1.4 & -3656960 \\
3100 & 5205 & -0.6 & -1292860 \\
3000 & 2616 & +1.3 & +1353730 \\
2900 & 810 & +2.1 & +685310 \\
2800 & 71 & +4.5 & +127744 \\
2700 & 23870 & -0.9 & -9020166 \\
\hline tota] & & & \\
\hline
\end{tabular}

The results show a decrease of the glacier in the upper regions and an increase below, which was also recognized qualitatively in Rü. Finsterwalder (1985), with another method.

The calculated change in volume can be used for the determination of the mass balance of the glacier, using the photogrammetric method as described in W.S.B. Paterson (1969).

\section{CONCLUSION}

In the presented paper, a method for the determination of changes in volume and elevation, using Digital Elevation Models, was introduced and applied. It could be shown that this method leads to about the same accuracy as the traditional contour method, but with an enormous economic gain, because no additional planimetric work is needed. Furthermore, the DEM now available allows for various applications such as:

- perspective views of the terrain

- orthophoto and stereo-orthophoto profiles

- general profiles

- contour plots of desired interval

slopes and slope maps

All these products are readily available from the DEM without additional measurement. These various possible applications, together with the greater economy, demonstrate that Digital Elevation Models are recommendable for glacier research.

\section{REFERENCES}

Brunner K, Rentsch H 1972 Die Änderungen von Fläche, Höhe und Volumen am Vernagt- und Guslarferner von 1889-1912-1938-1969. Zeitschrift für Gletscherkunde und Glazialgeologie 8(1-2): 11-25

Ebner H, Eder K 1984 Digitale Höhenmodelle heute und morgen. Mitteilungsblatt DVW [Deutscher Verein für Vermessungswesen], Bayern: 11-28

Ebner H, Reinhardt W 1984 Progressive sampling and DEM interpolation by finite elements. Bildmessung und Luftbildwesen 52: 172-178 
Ebner H, Hofmann-Wellenhof B, Reiss P, Steidler F 1980 A minicomputer program package for height interpolation by finite elements. International Archives of Photogrammetry 23(B4): 202-215

Finsterwalder R 1953 Die zahlenmässige Erfassung des Gletscherrückgangs an Ostalpengletschern. Zeitschrift für Gletscherkunde und Glazialgeologie 2(2): 189-239

Finsterwalder Rü 1985 Orthophoto - Selbstkontrolle. Bildmessung und Luftbildwesen 53: 72-74

Kraus K 1984 Photogrammetrie. Band 2. Theorie und Praxis der Auswertesysteme. Bonn, Dümmler Verlag

Paterson W S B 1969 The physics of glaciers. Oxford etc, Pergamon Press

Peipe J, Reiss P, Rentsch H 1978 Zur Anwendung des digitalen Geländemodells in der Gletscherforschung. Zeitschrift für Gletscherkunde und Glazialgeologie 14(2):
161-172

Reinhardt W 1984 A program for progressive sampling for the Zeiss Planicomp. 39th Photogrammetric Week at Stuttgart University, 1983. Stuttgart, Institut für Photogrammetrie der Universität Stuttgart: 83-90 (Schriftenreihe 9)

Rentsch H 1982 Die Orthophotokarte Vernagtferner 1979. Zeitschrift für Gletscherkunde und Glazialgeologie 18(1): $85-91$ 